\title{
Nostalgia of a Frustrated Ottoman Subject: Reading Osman Agha of Timișoara's Memoirs as Self-Narrative
}

\author{
R. Aslihan Aksoy Sheridan* \\ Basic Sciences Unit, TED University, Ankara, Turkey \\ ${ }^{\star}$ Corresponding author. E-mail: aslihan.aksoy@tedu.edu.tr
}

Ego-documents let us hear the voices of those who have been little heard in historiography. Such documents, especially when narrative in nature, provide insight into historical events and periods by illustrating how individuals-in correspondence with their own (in)actions, (in)decisions, and (mis)convictions as well as emotions, fears, aspirations, and frustrations-experienced and perceived these historical phenomena from a contemporary personal viewpoint. Since the revival of narrative historiography in the 1980s, partly in response to the Annales school, such documents have been increasingly recognized and employed as important historical sources. Nonetheless, the terminology for designating the generic nature and encompassing the diversity of such sources, as well as the methodology for historicizing them, remain under debate. ${ }^{1}$

The historiographical debate on ego-documents involves, in addition to generic and terminological concerns, many other aspects, including textual, contextual, and functional evaluations of these historical sources. Methodologically speaking, there have been two tendencies concerning ego-documents: one is to view them as sources for history writing, while the other takes them as objects of study in themselves. The latter approach, resulting in and from closer readings of these texts, strongly establishes that ego-documents are often elusive texts from which it is difficult or almost impossible to gather facts that can be taken at face value. ${ }^{2}$ Indeed, ego-documents must be studied beyond their literal textual level, considered within the context of their historical milieu, and approached in a dialectical manner so as to decipher the historical significance lying covert in their textual subtleties.

Ottoman ego-documents, despite growing scholarly interest in recent years, have been largely understudied: few self-narratives have been published in transliteration and fewer still studied with detailed attention paid to their textual and historical contexts on the one hand, and their narratological and rhetorical attributes on the other. What is more, regrettably the reception of ego-documents in Ottoman historiography has veered between two equally detrimental poles: one pole takes these sources at face value and in a fully descriptive manner, while the other neglects or often dismisses them based solely on factual grounds. ${ }^{3}$ Hence, despite the recent scholarly turn to manuscript libraries in pursuit of

\footnotetext{
${ }^{1}$ Despite controversies in the European historiography about the connotations of the prefix ego and its scope, I contend that "ego-document" signifies something more inclusive and practical, as an umbrella term, than terms like "first-person narrative" and "self-narrative" or "selbstzeugnis". It resonates with all varieties of historical sources-literary or nonliterary, narrative or nonnarrative-that record individual human experiences. In this regard, while the term "first-person narrative" can denote fictional or fictionalized narrative texts, "selbstzeugnis," frequently used in German scholarship, denotes texts that are more testimonial in nature. Based on this, here I will adhere to the more specific, and yet also more comprehensive, generic term "self-narrative"-as a narrative subgroup of "ego-documents" - in reference to Osman Agha's memoirs, where we encounter the self-fashioning of an individual in narrative form based on a retrospective self-recording of past experiences: "serimizden güzar eden ahvāl [ve] serencāmıñ bir mikdārın hikāyet țarīkiyle naḳl eylemek murād eyledik” (emphasis added); see British Museum, Or. 3213 (Istanbul, 1724), 2v.

${ }^{2}$ Rudolf Dekker, “Jacques Presser's Heritage: Egodocuments in the Study of History," trans. Diederik van Werven, Memoria $y$ Civilización 5 (2002): 30.

${ }^{3}$ Cemal Kafadar has crystallized scholarly interest in these historical sources and noted that the convergence of the influence of the Annales school with that of the opening of the Turkish archives has led to the positivistic approach in Ottoman historiography; see Cemal Kafadar, "Self and Others: The Diary of a Dervish in Seventeenth Century Istanbul and First-Person Narratives in Ottoman Literature," Studia Islamica 69 (1989): 122-23. The descriptive approach, on the other hand, has largely resulted from the fact that ego-documents remain in a liminal space between literary studies and historical analysis.

( $)$ The Author(s), 2021. Published by Cambridge University Press. This is an Open Access article, distributed under the terms of the Creative Commons Attribution licence (https://creativecommons.org/licenses/by/4.0/), which permits unrestricted re-use, distribution, and reproduction in any medium, provided the original work is properly cited.
} 
ego-documents, the state of the art of Ottoman historiography has yet to resolve the problem of how to study these texts and trace their historical significance.

In this study, I will attempt to steer clear of these two extremes and contextualize one particularly wellknown Ottoman self-narrative, namely the memoirs of Osman Agha (d. ca. 1732) of Timișoara (Turkish Temeşvar, Hungarian Temesvár, German Temeschwar). ${ }^{4}$ My main objective will be to use this text to put forth some preliminary observations on the historiographical evaluation of Ottoman self-narratives.

Because there are different kinds of Ottoman ego-documents, both literary and nonliterary and both narrative and nonnarrative, they have proven difficult to categorize, especially those of a literary nature, since similar terms have been used for differing or hybrid types of texts: these include autobiographical works like hāl tercümesi, șoḥbetnāme, and vāḳı'at (concurrently recorded self-narratives); sergüzeşt (retrospective records of life adventures); and so-called serencām (a quasi-generic denotation for retrospective records of life experiences). There are also diary-like records either courtly (ruznāme, cerìde), personal and miscellaneous $\left(\right.$ mecmū $\left.^{\mathrm{c}} a\right)$, or historiographical (tārīh or tevārih) in nature; dream logs (rüyānäme); and so on. Moreover, within the wider scope of ego-documents we also should consider the personal marginalia of single-text manuscripts (i.e., separate fascicles), miscellaneous manuscripts of a personal nature (i.e., mecmū'as), and hybrid texts such as travel books (seyahatnāme), as well as Ottoman court records (kadı sicili) and petitions (arzuhāl) that detail certain individual experiences. ${ }^{5}$ All these differing types of Ottoman ego-documents require their own methodologies-as do Osman Agha's memoirs.

Although these memoirs have been the subject of important studies based on transcription and factual examination via archival research, they have yet to be further contextualized as a self-narrative. Here, I examine this source not as the outward testimony of an historical experience-which is the main raison d'être behind more descriptive historiography-but specifically as a self-narrative that reveals the emotions and frustrations experienced by one particular Ottoman subject, in an effort to pinpoint how memory and self-fashioning work within these memoirs, particularly in conjunction with their historical context. I thereby aim to exemplify a preliminary dialectical approach toward Ottoman self-narratives.

Such a dialectical approach necessitates, first, the dictional, generic, narrational, and conventional configurations (e.g., cliché and literary patterns, or topoi) inherent in any act of recording; second, a larger frame of reference regarding the actual (i.e., personal and social) context surrounding the historical document in question; and third, an understanding of the inherently personal or political nature of recording. A dialectical study of historiography based on ego-documents calls, initially, for any established (mis)convictions of the historian to be set aside. ${ }^{6}$ Then, historiographical attention should be directed to three

\footnotetext{
${ }^{4}$ This particular self-narrative, the only known manuscript copy of which is today held in the British Museum (Or. 3213), has been introduced and published in various forms since 1950. Besides unpublished dissertations and introductory articles, the text was printed in an Arabo-Persian script version (with normalizing alterations) in 1980 by Richard F. Kreutel, and has also been transcribed into the Turkish Latin alphabet in both full-length (with alterations) and simplified versions, in addition to translations into German and French. Despite this long history of scholarly reception, the text has yet to be published in full, unaltered transliteration. For two important publications, among others, see Richard F. Kreutel, ed., Die Autobiographie des Dolmetschers 'Oșmān Aġa aus Temeschwar (Hertford, UK: EJW Gibb Memorial Trust, 1980); and Harun Tolasa, ed., Kendi Kalemiyle Temeşvarlı Osman Ăga (Bir Osmanlı Türk Sipahisinin Hayatı ve Esirlik Hatıraları) (Konya, Turkey: Selçuk Üniversitesi Yayınları, 1986). Also, for an important recent article uncovering significant details through archival research of Osman Agha's life experience after the writing of his memoirs, see Ömer Gezer, "Temeşvarlı Osman Ağa-Esir, Tercüman ve Yazar,” Türkbilig 35 (2018): 73-88. Gezer here clarifies a prevalent confusion about Osman Agha’s initial identity, emphasizing that he had actually held a salaried post of the farisān - the cavaliers of strongholds in Ottoman border territories-before his captivity; see ibid., $75 \mathrm{n} 2$.

${ }^{5}$ The latter examples especially call for a different methodology than integral texts, needing to be stitched together to illustrate the micro-histories of individuals or groups. A belated necessity in this field is the establishment of an inventory for Ottoman ego-documents, which would allow for a better understanding of their scope, nature, and diversity and provide the ground for such methodological inquiries; the workshop on Ottoman ego-documents held at Istanbul Medeniyet University on 11-13 March 2020 paved the way for the creation of such an inventory.

${ }^{6}$ This issue is often disregarded in historiographical circles, but self-recognition of the historian's own established convictions is paramount, as they may otherwise be foisted on the historical text and context to be studied. Such (mis)convictions might very well be based on personal and yet ideological, as well as on impersonal and yet disciplinary grounds, and include the dichotomy between fact and fiction that is rigorously endorsed in historiography; the search for authenticity, originality, and Urforms at the
} 
aspects of the particular source: the text itself (content + form), its context (social + personal), and its function (social + personal). As is the case with every rhetorical situation, evaluation of these sources requires focus on why (context) and for what purpose(s) (function) the text at hand has been written, along with the question of how (form) it was written, and therefore necessitates a mindful suspension of lingering merely on what (content-wise) might be mentioned in the source.

Contrary to such a dialectical approach, the two earlier specified poles (i.e., descriptive reproduction and dismissal based on factuality), which have led to an unfavorable reception of Ottoman ego-documents, concentrate solely on the content of the text, either to reproduce or to refute it, yet both of these polarized approaches typically neglect to investigate the form (how), the contextual contingencies that led to the production of the historical text (why), and the attempted function(s) of the text (for what purpose). Contrary to these approaches, I will here refer briefly to the content of Osman Agha's memoirs to pay due attention to the aforementioned three aspects (text, context, and function) and their related questions.

Starting with the first aspect, relating to text (content + form) and its first related question of what is recorded content-wise, Osman Agha's account records his experience from childhood to adolescence, especially after the loss of his parents, and on into his early youth - when he joined raids on bordering European territories-up to his official appointment as a serhad kulu (an Ottoman salaried subject on the borderlands) before moving on to his eleven-year captivity in Austrian lands, which is much detailed in the narrative. These recorded past experiences give glimpses into the typical lives of kuloğlu (sons of borderland subjects), with both Osman Agha and his elder brother, Bektaş Agha, who were able to secure an inherited salaried position thanks to their father Ahmed Agha's position and network in the Ottoman borderlands. ${ }^{7}$ Another typical aspect of the historical period revealed in the content of Osman Agha's narrative is its report of the conventional practices and wrongdoings of ransom slavery, which Osman Agha himself experienced in the Ottoman-Habsburg borderlands around the turn of the 18th century. In terms of their content, then, these memoirs can be recognized as records of relatively ordinary or even typical experiences of a kuloğlu on the frontier.

Osman Agha's case also exemplifies that the borderlands provided a degree of security, upward mobility, and even a small measure of self-reliance, for Ottoman serhad kulus: returning to Timișoara from captivity, Osman was immediately reinstated to his former post and paid his outstanding wages ('ulüfe). ${ }^{8}$ Also, his ability to speak German subsequently provided him with an opportunity to work as a divan dragoman in an official capacity. ${ }^{9}$ Before this new post, Osman Agha records having refused an offer to join the retinue of Ahmed Pasha, governor of Timissoara province at the time: "To go now and be a pasha's servant and partake in his retinue would seem shameful to me, [so] I didn't join [Ahmed] Pasha. However, I called constantly at the [pasha's] household, and whenever an Austrian came I would do translation work." 10 As the subsequent period of prosperity in his life between 1699 and 1724 indicates, the choice not to join Ahmed Pasha's retinue worked out well-but only until his benefactors, the ambassadors Ibrahim Pasha and 'Ali Pasha, were gone. ${ }^{11}$ Once he had to flee to Istanbul, having lost his benefactors and belongings, Osman had no patron to whom he could turn.

Given the situation, the self-narrative in his memoirs can be viewed as an effort to acknowledge and remind himself (and possibly others) of his past background, achievements, and merits, and thus represents one particular individual expression of an experience quite typical for Ottoman kuls, whose

price of losing sight of the effects of generic configurations or the historical significance and effect of different historical contexts; and even regarding people of the past as if they were a species of alien categorically different from their modern counterparts. (Mis)convictions like these are deeply rooted, and they very often affect the way history is written.

${ }^{7}$ Gezer also notes these and other typical, or "ordinary" ("siradan"), aspects of Osman Agha's experiences as a serhad kulu in detail; see "Temeşvarlı Osman Ağa," 74, 76-83.

${ }^{8}$ British Museum, Or. 3213, 123r; see also Kreutel, Die Autobiographie, 97; and Tolasa, Kendi Kalemiyle, 168.

${ }^{9}$ Osman Agha indeed served during local negotiations of the disputes and formal inauguration of the border between the Ottoman and Austrian empires, and elsewhere; see Gezer, “Temeşvarlı Osman Ağa," 79-80 and footnotes 30-31.

${ }^{10}$ British Museum, Or. 3213, 119r; see also Kreutel, Die Autobiographie, 94; and Tolasa, Kendi Kalemiyle, 164.

${ }^{11}$ Gezer, "Temeşvarlı Osman Ağa," 80-81, 82; see also Richard F. Kreutel, Zwischen Paschas und Generälen-Bericht des 'Osman Ağa aus Temeschwar über die Höhepunkte seines Wirkens als Diwansdolmetscher und Diplomat (Graz, Austria: Verlag Styria, 1966). 
livelihood-especially during the tumultuous years of the late 17th and early 18th centuries-depended on successfully navigating within the patronage system. I contend that Osman Agha's memoirs can indeed be read as a kind of résumé (rather than a more factual curriculum vitae) recorded in narrative form. What is atypical about Osman Agha's memoirs, however, is the very fact that they were recorded, and moreover recorded in the way they were, with vivid detail presented in the context of an adventureladen self-narrative.

As for the text's form, and specifically the question of its style and generic configurations (how), Osman Agha's memoirs present an action-packed, riveting, and almost picaresque self-narrative. Although Ottoman historiography categorizes his memoirs as a captivity narrative (esaretnāme) based on their content, Osman himself denotes his narrative content with the phrase "ahvāl [ve] serencäm" (lit., "conditions [and] consequence"). ${ }^{12}$ For such narratives full of adventure, the generic term "sergüzeşt" (lit., "escapade" or "adventure") was in fashion in Ottoman literature. Unlike the term "serencām" (which might be considered a quasi-generic term denoting a retrospective outlook of plotting in the narration), "sergüzeşt" at least semantically connotes a concurrent narration or resolution after a series of adventures. However, when Osman Agha wrote his memoirs, he was not in a state of "relief after distress" (el-ferec ba'd eş-şidde), as "sergüzeşt" would suggest. ${ }^{13}$ On the contrary, he was frustrated with his current conditions at the time of his recording, which lends both sense and poignancy to his use of the phrase "ahvāl [ve] serencām". The narrative's paratextual elements-found in both the introductory and concluding sections-indeed accentuate Osman Agha's very act of remembering the past in the present moment, implicitly contrasting his current experience, living in Istanbul in 1724, with his earlier experiences. ${ }^{14}$

As for the second aspect, relating to context (social + personal), one might still further ask: why was this particular self-narrative written at the time it was, in 1724 , in the Ottoman capital of Istanbul? ${ }^{15}$ That is to say, what social and personal conditions motivated Osman Agha to recall and then record his experience in the dāru'l-harb (non-Muslim territory) of Habsburg lands more than two decades after his return to the dāru'l-İslām (Muslim territory)? The Ottoman loss of central European territories, coupled with its diminishing claims to sovereignty in Europe, especially after the 1699 Treaty of Karlowitz, seem to have led some to a feeling of "failure," while still others in court circles unambiguously strove to rationalize these losses, as recorded in contemporary chronicles and other court documents. ${ }^{16}$ Afterward came what modern Ottoman historiography based on this courtly perspective calls the "Tulip Age," a period of relative peace extending from the 1718 Treaty of Passarowitz to the 1730 Patrona Halil revolt. ${ }^{17}$ Reading Osman Agha's memoirs against this backdrop, one can pinpoint relevant parallels to what Osman recalls experiencing as an individual, first in Austrian captivity and later as a dragoman in the Ottoman-Habsburg borderlands. Ottoman territorial losses in southern Hungary and Transylvania indeed culminated in the capture of Timișoara, Osman's birthplace, by the Habsburgs in $1716 .{ }^{18}$ In the memory of Osman Agha, in contrast to recorded courtly justifications, these lost territories, including his hometown, seem to

\footnotetext{
${ }^{12}$ See British Museum, Or. 3213, 2v.

${ }^{13}$ For an extensive study on Ottoman self-narratives in verse (manzūm sergüzeştnāmes), including summaries, see Haluk Gökalp, Eski Türk Edebiyatında Manzum Sergüzeşt-nāmeler (Istanbul: Kitabevi, 2009). For the term "el-ferec ba'd eş-şidde" and similarly titled collections of stories, see György Hazai and Andreas Tietze, Ferec Ba'd Eş-Şidde "Freud Nach Leid" (Ein Frühosmanisches Geschitenbuch), vol. 1 (Berlin: Klaus Schwarz Verlag, 2006).

${ }^{14}$ Following his eleven-year captivity under three different Austrian masters, Osman Agha escaped to Ottoman territory after the 1699 Treaty of Karlowitz. For the next seventeen years, he lived in Timişoara and Belgrade, until their capture (in 1716 and 1717, respectively) by the Habsburgs, then in Vidin. Around 1724, he had to leave for the Ottoman capital due to further Ottoman territorial losses, leading to personal losses as well. See also footnote 19.

${ }^{15}$ British Museum, Or. 3213, 123v; see also Kreutel, Die Autobiographie, 98; and Tolasa, Kendi Kalemiyle, 170: "Written by this humble one, full of fault, the dragoman Osman Agha of Timișoara, in the Tophane quarter of Istanbul, on 24 Sha'bān 1136 [18 May 1724].”

${ }^{16}$ For the Ottoman courtly experience in this period, see Tarih-i Râşid, vol. 4 (Istanbul: Matbaa-i Amire, 1865-1866), 193-215. For the Ottoman chronicler Mustafa Naīmā's ambivalent reaction to the Treaty of Karlowitz, see Rifaat A. Abou-el-Haj, "The Formal Closure of the Ottoman Frontier in Europe: 1699-1703," Journal of the American Oriental Society (1969): 467-71.

${ }^{17}$ Ahmed Refik [Altınay] (1881-1937), borrowing a conceit from the 18th-century poet Nedim, coined the phrase "Tulip Age" (Lâle Devri) in 1912; see Can Erimtan, Ottomans Looking West? The Origins of the Tulip Age and its Development in Modern Turkey (New York: I. B. Tauris, 2008), 23.

${ }^{18}$ Géza Dávid notes not only Timișoara's 164-year history under Ottoman rule and its importance for the Ottoman claims in Europe, but also records how Ottomans were keenly aware of its immensely greater strategic importance after 1699, as before its
} 
have lingered on and/or been recollected afterward as a great individual and personal loss and a greater source of frustration, especially given his present situation in Istanbul. Osman Agha's felt need to retrospectively record his experience of captivity more than two decades after the fact seems to have been incentivized when he took refuge in Istanbul, having lost in the now no longer Ottoman borderlands many family members (including a wife, two daughters, and four sons) as well as his prosperity and any future prospects. The emotional underpinnings of this need come to the fore when, near the end of his narrative, Osman summarizes what he experienced in Timișoara after his escape and so hints at what brought him to Istanbul, emphasizing the theme of the transitory nature of all human life, great and small:

In Timișoara, I had three daughters with my previous wife. Then I had five sons. One of the daughters is alive now; I have married her to a man in Istanbul. Of my sons, only Isma il is alive; the others have all passed away. In seventeen years in Timișoara I gained numerous possessions and emoluments, as well as two tımar holdings. Later, 'Ali Pasha, who was killed at Petrovaradin, granted me personally the zeamet of Yarkofça, sending my son Isma'il there. In the material world we obtain many things and, thinking that nothing will go too bad so long as life is granted us, we aim to spend our time in the pursuit of pleasure-but this world is treacherous and nothing remains for anyone, no matter how insignificant we may seem. So many great rulers in the past, those written of in books of history, said, "The world is mine!"- and now neither their name nor any trace of them remains. ${ }^{19}$

This paratextual note provides a glimpse into not only the contextual contingencies (i.e., the why) leading up to Osman Agha's enactment and recovery of his past through this self-narrative, but also the text's possibly intended function(s) (i.e., the question for what purpose). Osman seems to hint that he had been recognized even in the dâru'l-harb (non-Muslim territory) for his merits, more than he was in the Ottoman capital. ${ }^{20}$ Indeed, Osman Agha's experience in Istanbul was nothing like his earlier life experience, as he was in dire straits, living in the Tophane district, teaching Turkish to European dragomans just to make ends meet, and clearly feeling unappreciated: "A noble hadith establishes that the believer must suffer three calamities. The first of these is illness; that is, sickness and disease in the body. The second is poverty. The third is being the object of contempt; that is, to be a superfluity to this world. The three all go together. Praise be to God the exalted, I have had all three of them." ${ }^{21}$ Coupled with the aforementioned remembrance of his time before Istanbul, this passage evokes a bittersweet nostalgia for the recovery of the past through personal restoration via memory of a previous self as well as the now lost Ottoman territories Osman had once called home. He ultimately "reclaims" these lost lands by reproducing them in great spatial detail, including the towns, districts, rivers, directions, and distances left behind when he escaped.

Previously a soldier, Osman indeed evinces a stronger spatial than temporal orientation in his recollection and record of his past experiences. In this regard, earlier studies of Osman Agha's memoirs have emphasized their relatively frequent chronological and/or factual discrepancies. ${ }^{22}$ Such discrepancies seem to fall into two categories: unintentional mistakes made due to reliance on memory, even in the dating of events of personal importance to Osman, and somewhat deliberate "mistakes" that help Osman Agha to fashion his self in the narrative. The first category includes, for instance, dating the

fall it was the last remaining Ottoman fortification north of the Danube; Géza Dávid, “The 'Eyalet' of Temesvár in the Eighteenth Century," Oriente Moderno 18 (79), no. 1 (1999): 113.

${ }^{19}$ British Museum, Or. 3213, 123r; see also Kreutel, Die Autobiographie, 97; and Tolasa, Kendi Kalemiyle, 168-69.

${ }^{20}$ Although Osman Agha had been treated badly by his first Austrian master, Fischer, an officer of middling rank whom he represents as a lowly character who refused to release him even after due ransom had been paid, he records better conditions with General Graf Stubenberg, who took him to his castle near Kapfenberg (Styria), and later in the household of the Court War Councilor General von Schallenberg in Vienna, where he notes having been treated fairly and respectfully, by the mistress of the household especially; see British Museum, Or. 3213, 49r-63r.

${ }^{21}$ See British Museum, Or. 3213, 123r; see also Kreutel, Die Autobiographie, 97; and Tolasa, Kendi Kalemiyle, 169; emphasis added.

${ }^{22}$ Chronological accuracy might well suit modern researchers' needs and proclivities, and indeed many researchers seem to have a tacit assumption that any historical recollection is directed to themselves as potential recipients. However, when Osman Agha chose to pen his self-narrative, his assumed audience seems to have been a much more immediate one, meant to help secure his livelihood given his precarious state in Istanbul. 
Habsburg capture of Lipova to June/July 1687, even though Osman's capture, which took place on 11 June 1688, occurred during this siege. Similarly, he records the Treaty of Karlowitz as having taken place in 1700, explicitly giving the Christian date, rather than January 1699. These mistakes may have been due to either his memory being affected by his own personal experience, thus prolonging his captivity in connection with the actual dates of his capture and eventual escape, or to the de facto delay in the enactment of the treaty's article about the emancipation of captives on both sides due to economic concerns of value and expenses. ${ }^{23}$ As for more deliberate mistakes, Osman Agha names, not Ibrahim Pashawith whom he worked during negotiations on border disputes from 1701 onward-as the governor of Belgrade during the 1707 Kecskemét negotiations, but rather Köprülüzade 'Abdullah Pasha, who would take the position only in $1710 .{ }^{24}$ This is possibly due to the fact that Ibrahim Pasha, who was ambassador in Vienna in 1718-20 and had been Osman's benefactor during his work as a dragoman, had died in 1720, but Köprülüzade Abdullah Pasha was still active as the newly appointed governor of Tabriz, with a track record of military successes-and therefore was still a potential connection for patronage. In this respect, what Osman omits in his memories is also telling: he never mentions the uprising that occurred in the Timișoara garrison for delayed payments of wages ('ulüfe) and led to the murder of the then governor, (a different) Ibrahim Pasha, and the subsequent assignment to the post of Cafer Pasha, who would send Osman to Lipova to retrieve money for those delayed payments. And it was this trip, in 1688, that resulted in his capture. ${ }^{25}$ This omission seems to suggest Osman's possible involvement in the said uprising, and may well have been intentional for the sake of self-fashioning on his partas well as being something useful to conceal if Osman's memoirs were at least in part meant to secure himself patronage.

This leads us to the third, and last, aspect, related to function (social + personal), and its associated question of for what purpose. In this regard, one might ask: what led Osman Agha to record his experience as a retrospective self-narrative? A related but more methodological problem to considerespecially significant for early modern self-narratives dealing with captivity-is the question of the dichotomy between fact and fiction. ${ }^{26}$ The functionality surely opens up the possibility of some degree of fictionalization in the plotting of any self-narrative. Therefore, scholarly attention needs to be paid to texts' particular historical context(s) and the incentive behind their production and reproduction. Ultimately, albeit with certain reservations, every historical source, however factual or fictional it may be, can be the object of historiographical inquiry: after all, no historical document comes, or can ever come, with a foolproof license of authenticity attached. ${ }^{27}$ Relevant questions need to be directed about possible intention(s) and the assumed audience(s) to open up such texts' historical significance in connection with the historical context within which they were produced, received, and reproduced.

To look at Osman Agha's memoirs with all this in mind, they certainly evince a critical stance toward others based on his own personal moral compass, but they do not include the essentialist representations of specific people or groups typically encountered in politically or confessionally propagandistic narratives: in what Osman writes, Austrians, Armenians, Serbians, and Muslims all have both sympathetic and unsympathetic representatives. ${ }^{28}$ Nevertheless, the memoirs are, in a manner of speaking,

\footnotetext{
${ }^{23}$ Tolasa, Kendi Kalemiyle, 45 n9; and Gezer, "Temeşvarlı Osman Ağa," 75 n3; see also Karl Teply, "Vom Los osmanischer Gefangener aus dem grossen Türkenkrieg 1683-1699,” Südost-Forschungen 32 (1973): 33-72.

${ }^{24}$ Gezer, “Temeşvarlı Osman Ağa,” 79-80 n11.

${ }^{25}$ Ibid., 75.

${ }^{26}$ Some captivity (and conversion) self-narratives that detail both sides of the Ottoman-Habsburg divide were written as political (or confessional) propaganda. Cemal Kafadar notes that "memoirs of captivity pose potential risks as examples of personal literature, for they may be reflections of a literary device rather than actual lived experiences"; see "Self and Others," 132. For some Ottoman conversion self-narratives as confessional propaganda, see Tijana Krstić, Contested Conversions to Islam: Narratives of Religious Change and Communal Politics in the Early Modern Ottoman Empire (Stanford, CA: Stanford University Press, 2011).

${ }^{27}$ Another possible (mis)conviction on the part of historians would be to consider all self-narratives of captivity to ipso facto serve a hidden agenda, whether political or ideological, before actually studying each individual self-narrative in its own right in a dialectical manner.

${ }^{28}$ The Hungarians, tellingly, are an exception to this apparent impartiality. A more detailed study focused on different representations in this and other self-narratives can perhaps yield further insight into the related historical contestations of the period.
} 
propagandistic-but for the self rather than for any overt or covert political or confessional ends. In fact, as has been mentioned, the narration has the air of a kind of unofficial petition for the recognition of Osman's past experience and personal merits. It is thus a form of self-promotion, although in a mode more humble than outright boasting.

Like any evocation of the past self through memory, then, this narrative inherently results in an act of self-fashioning, which in turn incorporates fictionalized elements, clichés, and topoi: the persona of Osman Agha in the narrative is a man who vehemently refuses to convert to Christianity despite being presented with many opportunities, and who is confident and clever enough to deceive Austrian governors thanks to both his forgery of documents of passage and to his skill in disguise. ${ }^{29}$ Starting off like this, much like a picaro, he escapes captivity and flees, and later is sought after as a dragoman in the Ottoman borderlands thanks to his range of abilities. And it was not until he was in his fifties, long after his escape and his work in the borderlands where he made and lost a fortune, that Osman Agha wrote his memoirs: the narrative thus presents a text in which the first-person narrator looks back into his own past and fashions a picture of his younger self. Osman Agha's memoirs entail selfpromotion via retrospective self-fashioning-rather than a factual testimony-and formed his first attempt at writing a résumé for securing possible future patrons in Istanbul. ${ }^{30}$ Given the fact that Osman Agha records, as described above, how he was initially appalled by the idea of becoming "a pasha's servant and partak[ing] in his retinue" when he first returned from the dâru'l-harb (non-Muslim territory) to Ottoman lands, his ultimate immersion into the matrix of the patronage system and its factional disputes is bitterly ironic, although also quite revealing of how contemporary sociopolitical changes eventually affected him personally. ${ }^{31}$

Modern historiography has, until relatively recently, concentrated on retrieving historical facts about the periods under examination: most historical or historiographical works and texts have been treated merely as sources of factual evidence about the periods, environs, and events they relate. Such evidence has typically been analyzed with a somewhat positivist outlook and in a tentatively comparative manner so as to be considered and included among either "canonical" historical texts or else dismissed altogether as "unhistorical." As part of this normative process of historiography, the inherent capacity of texts to reveal (mis)perceptions, (mis)conceptions, and (mis)convictions-all of which also need to be historicized-has generally been neglected. However, such emotional and personal points of interest suggest that ego-documents might prove as revealing as official documents. While the latter reproduce a mainstream ideological stance toward and outlook on political adversaries and enemies, self-narratives like Osman Agha's memoirs not only reveal the emotional undercurrents lying behind and even motivating such an outlook, but also can provide a historical understanding of the individual occurrences and

\footnotetext{
${ }^{29}$ The narration puts forth the Osman Agha persona as a "survivor" and a kind of trickster, as someone who has undergone numerous trials, temptations, and difficulties but still managed to overcome them all. See, for example, British Museum, Or. 3213, 85v-86r; see also Kreutel, Die Autobiographie, 67-68; and Tolasa, Kendi Kalemiyle, 129-30: "I also took with me four big bottles of good Tokaj wine and some Tyrol and other kinds of wine [. . . some food, bedding, and blankets; and a complete set of firearms, namely a couple of excellent pistols, an excellent musket, and a carbine. I had long, black hair and wore a shirt made of Genoese linen with white thread embroidery and tight-fitting trousers [. . . I looked like a low-ranking officer, and no one who saw me would have thought I was a Muslim."

${ }^{30}$ To attain such recognition, he also would record his work as a dragoman in the borderlands as a kind of sequel to this first résumé; namely, a history ( $t \bar{a} r \bar{\imath} h$ ) detailing the official correspondence Osman Agha kept during the 1707 Kecskemét negotiations. Osman mentions this in his memoirs as an implied intended work, and this "history" has been published in German translation; see Kreutel, Zwischen Paschas und Generälen. For Osman's mention of this intended work in his memoirs, see British Museum, Or. 3213, 122v; see also Kreutel, Die Autobiographie, 98; and Tolasa, Kendi Kalemiyle, 168: "[In Belgrade,] certain councils had been held for the conditions of the negotiations, [and] if all these were to be written down, it would have to form a 'history' [tārīh]."

${ }^{31}$ It should be underlined here that Gezer's thorough research into Austrian archival documents has corrected the approximate date of death for Osman Agha of 1725, put forward by Kreutel and Tolasa. It seems that Osman was indeed eventually recognized by court circles and reappointed as a dragoman on the borderlands, where he served until about 1732, taking part in factional conflicts around Şehbender Ömer Agha, with whose party he had revisited Vienna, and he later worked as a dragoman in Vidin, finding other patrons like Topal Osman Pasha; see Gezer, “Temeşvarlı Osman Ağa," 85-86.
} 
de facto political situations that are experienced on the ground at a given historical moment-but that, for reasons both practical and ideological, are not fully given voice in official documents. Unlike the largely black-and-white picture provided by official documents like imperial decrees and chronicles, historical self-narratives capture the actual conditions and dimensions of historical periods of conflict and contestation, and the individuals who lived through them-vividly and in full color.

Cite this article: Aksoy Sheridan RA (2021). Nostalgia of a Frustrated Ottoman Subject: Reading Osman Agha of Timișoara's Memoirs as Self-Narrative. International Journal of Middle East Studies 53, 323-330. https://doi.org/10.1017/ S0020743821000386 